\title{
Jarosław Rutkowski
}

\section{Praca socjalna w mieście. Perspektywa koinopolityczna}

\section{Social work in the city. Prospect of the koinopolis}

\begin{abstract}
A B S TR A C T: Social work sensitive to meeting man, strongly connected with the pulsating experience of human lives, take the effort of effective relief operations with concern for the dignity and human agency. Reflection on social work in meeting with "point" of human experience affected by the suffering, it shapes possibilities for creative and emancipatory for so undertaken social practice. The aim of this paper is to look at the social work in the koinopolis perspective in the context of the subjectivity and social inclusion. Significant for the theory and practice of social work in view of the koinopolis is to undertake the point of human experience and the extraction of it to expand the local community experience and knowledge. This social practice for human recovery returning to society, can effectively develop the community of thought and the common knowledge socially useful for agreement and cooperation.
\end{abstract}

KE Y W O R D S: Meeting, point, plasticity, emancipation, koinopolis.

ST R ES Z C Z E N I E: Praca socjalna wrażliwa na spotkanie człowieka, wyrastająca z pulsujących doświadczeń ludzkich losów, podejmuje wysiłek skutecznych działań pomocowych z troską o godność i sprawczość człowieka. Refleksja nad pracą socjalną w mieście w perspektywie spotkania z „punktowym” doświadczeniem człowieka dotkniętego cierpieniem, kształtuje możliwości kreacyjne i emancypacyjne dla tak podejmowanej praktyki społecznej. Celem niniejszego artykułu jest odczytanie pracy socjalnej w perspektywie koinopolitycznej w ramach splotu zagadnienia podmiotowości i społecznej inkluzji. Znaczące dla teorii i praktyki pracy socjalnej w perspektywie koinopolis jest podjęcie punktowego doświadczenia człowieka i wydobycie go na rzecz poszerzania doświadczenia lokalnego. Ta praktyka społeczna na rzecz odzyskiwania człowieka powracającego do społeczeństwa, może skutecznie rozwijać wspólnotę współmieszkańców, wspólnotę myśli lokalnej wytwarzającą wiedzę społecznie użyteczną na rzecz porozumienia i współpracy.

SŁOWA KLUCZOWE: Spotkanie, punkt, plastyczność, emancypacja, koinopolis. 


\section{Wstęp}

Miasto jako zjawisko społeczne jest wciąż aktualnym tematem refleksji i przedmiotem badań naukowych (Kunce 2016; Mendel 2017; Sagan 2017; Skórzyńska 2017). Życie w mieście pełne jest dynamicznych procesów politycznych, ekonomicznych, społecznych. Mieszkańcy miasta codziennie mają możliwość rozwijania wzajemnych relacji rodzinnych, sąsiedzkich, pomocowych, zawodowych, handlowych, urzędowych. Doświadczenie spotkania w perspektywie życia w mieście jest kluczowe. W przestrzeni miasta gromadzą się różnorodne idee, interesy, których wyrazicielami są mieszkańcy, ale także politycy, przedsiębiorcy, turyści. Kształtowanie przestrzeni dialogu przez użytkowników miasta czyni go otwartym na spotkania $\mathrm{z}$ Innym. Ważną rolę $\mathrm{w}$ tym może pełnić aktywność mieszkańców, stanowiąca nieokreślony zbiór punktowych doświadczeń, których usytuowanie wypełnia różnorodne przestrzenie miasta.

Otwarcie na tę wielość spotkań miejskich jest istotne w interpretowaniu doświadczenia miejsca (Kunce 2016; Mendel 2017 i in.). Szlaki spotkań znaczone śladami doświadczeń społecznych są wskazaniem nieskończonej sieci współtworzącej miejsca, w których istniejemy. W pejzażu miasta widoczne są również osoby cierpiące, odrzucone, pomijane, ale także swoiście wygrodzone z pełnego dostępu do decydowania o życiu w mieście. Stąd podejmowane są działania na rzecz zmiany życiowego usytuowania takich ludzi. Tworzenie warunków dla tej zmiany wymaga aktywności na rzecz poszukiwania i projektowania nowych rozwiązań we współpracy z człowiekiem potrzebującym wsparcia, zamieszkującym $\mathrm{w}$ danym miejscu oraz we współpracy $\mathrm{z}$ osobami, instytucjami $\mathrm{z}$ danego środowiska lokalnego.

Ważną rolę $\mathrm{w}$ tych działaniach odgrywa praca socjalna (Sokołowska i in. 2014). Praca socjalna traktowana jako remedium na wyobcowanie, odrzucenie, jako odzyskiwanie człowieka powracającego do społeczeństwa, niekiedy trwale wpisanego $\mathrm{w}$ zniewalającą go przestrzeń. Praca socjalna jako mediowanie pomiędzy obliczem miasta swoiście wygrodzonego, nieczułego, a obliczem miasta włączającego, troskliwego o dobro ludzi i ich prawo do miasta, może kształtować wspólnotę współmieszkańców, a tym samym wspólnotę myśli lokalnej wytwarzającą wiedzę społecznie użyteczną na rzecz porozumienia i współpracy. Popularne za sprawą Henriego Lefebvre’a (ostatnie trzy dziesięciolecia XX wieku) i Davida Harveya (pierwsza dekada XXI wieku - aktualnie) „prawo do miasta”, to więcej, niż przypisywane mu znaczenie indywidualnej wolności dostępu do zasobów miejskich, to prawo do zmieniania siebie poprzez zmienianie miasta (Sagan 2017). 
Artykuł jest próbą umiejscowienia pracy socjalnej w przestrzeni praktyk społecznych na rzecz rozwijania wspólnotowego miasta. Miasto odczytywane jest jako splot synergicznych działań, konstytuujących miasto edukacyjne (Mendel 2016). Rozważania nad pracą socjalną są prowadzone w ujęciu interpretatywnym rzeczywistości społecznej, z wykorzystaniem myśli antropologii lokalności (Aleksandra Kunce), filozofii plastyczności (Catherine Malabou) oraz pedagogiki miejsca (Maria Mendel).

\section{Doświadczenie spotkania}

Kluczową kwestią w podejmowanej tu myśli o pracy socjalnej jest postawa otwartości pracownika socjalnego na doświadczenie spotkania z człowiekiem. Wychodząc od wydarzenia spotkania w horyzoncie miejsc, możliwe staje się podjęcie pracy socjalnej w rozumieniu jej jako wyzwania, pracy społecznej na rzecz relacyjnej zmiany człowiek-człowiek oraz człowiek-miejsce-człowiek. Stąd podejmowane zagadnienia odczytywane będą w humanistycznym podejściu do pracy socjalnej według Ewy Marynowicz-Hetki (Marynowicz-Hetka 2012, s. 110) zorientowanym na relacyjną pracę socjalną, która nabiera wymiaru pracy społecznej i w ten sposób sprzyja tworzeniu społeczności/wspólnoty. Eksponuje działania mające charakter wzajemnego konstruowania rzeczywistości, jej przekształcania, w dzieleniu wartości uzgadnianych w podejściu mediacyjnym i solidarnościowym. Relacyjny model działania jest realizacją kultury działania, wyrastającej z kultury dialogu i potrzeby myślenia według wartości. Józef Tischner akcentował potrzebę myślenia według wartości (Tischner 1994). Podkreślał on, że „doświadczenie drugiego człowieka oznacza otwarcie dla mnie etycznego horyzontu mego istnienia. W ramach tego horyzontu ja jako człowiek obcuję z drugim jako człowiekiem. Dobro drugiego jest sprzężone $\mathrm{z}$ moim dobrem, a moje dobro $\mathrm{z}$ dobrem drugiego" (Tischner 1994, s. 387-388).

W pejzażu różnorodnych spotkań pracownik socjalny często doświadcza u osób, z którymi pracuje, ich krzywdy, zagubienia, bezsilności, odrzucenia. Jak wskazuje J. Tischner: „Doświadczamy innego, spotykając go. Spotkać to coś więcej niż mieć świadomość, że inny jest obecny obok mnie lub przy mnie. Spotkanie jest wydarzeniem. Spotkanie pociąga za sobą istotną zmianę w przestrzeni obcowań. To całkiem Inne uobecnia się w twarzy innego i wzywa człowieka ku czemuś, co jest poza bytem i niebytem" (Tischner 2006, s. 19-20).

Józef Tischner podkreślał jednocześnie, że spotykając Innego, spotykamy go „w jego twarzy”. Poszukując jej odczytania, opisywał aktywne jej oblicze: „Twarz to postać ludzkiej niezgody na to, że «życie prawdziwe jest nie- 
obecne». Twarz to wyraz egzystencjalnego ruchu, w którym człowiek stara się usprawiedliwić, to że jest, oddając swe istnienie pod ochronę przynoszącego mu nadzieję dobra" (Tischner 2006, s. 64). Praca socjalna poszukująca i pozostająca $\mathrm{w}$ dialogu $\mathrm{z}$ doświadczeniem człowieka, kreuje przestrzeń obcowań wyzwalającą od cierpienia i zagubienia społecznego. To praktyka społeczna wrażliwa na historie ludzkiej nieobecności w życiu miasta i otwarta na animowanie zmiany społecznej.

Pracownik socjalny podejmując się projektowania pracy socjalnej i realizacji indywidualnych programów pomocy, kieruje się zasadami etyki zawodowej oraz zasadą dobra osób i rodzin, którym służy, poszanowania ich godności i prawa tych osób do samostanowienia ${ }^{1}$. Jednocześnie, animując społeczną aktywność osób, rodzin, grup i środowisk społecznych, a także inicjując nowe formy pomocy dla nich, projektuje z udziałem zainteresowanych osób mapę miejsc służących przedmiotowym działaniom. To miejsca ważne i znane w środowisku lokalnym osobie zainteresowanej współpracą, a także miejsca być może dotychczas nieodkryte, w tym centra twórczości, wolontariatu, domy sąsiedzkie. Praca socjalna realizowana $\mathrm{w}$ mieście jest otwarta na spotkania ludzi aktywnie zaangażowanych z ludźmi poszukującymi miejsca do własnej aktywności.

Troska o potwierdzenie obecności człowieka w przestrzeni miasta nadaje pracy socjalnej wymiar emancypacyjny. To potwierdzenie może wyrażać się w projektowaniu, nazywaniu, a wreszcie fizycznym poznawaniu miejsc miasta, w których prezentuje się własne poglądy, własną twórczość, gdzie wspólnie spędza się czas w ramach różnorodnych zajęć i aktywności na rzecz innych. Z czasem wspólnie wypracowane kierunki działań pomocowych nakreślone na mapie lokalnej potencjalności społeczno-kulturowej mogą przybrać postać witalnej energii, kształtującej zindywidualizowaną zmianę społeczną. Działania osób wymagających wsparcia i współpracujących z pracownikiem socjalnym nabierają wówczas formy wyzwalających od niemocy, „punktowych” doświadczeń, rozwijających wzmocnione lub odzyskane zdolności do funkcjonowania w społeczeństwie.

Wobec rozważanej pracy socjalnej w perspektywie doświadczenia spotkania ważną rolę przypisać należy współczesnym konceptom miejskości, podejmującym analizy procesów złożonych form akcji i interakcji wytwarzających miejską rzeczywistość (Skórzyńska 2017, s. 59). Agata Skórzyńska

1 Art. 119 ust. 2 pkt 1 i 2 ustawy z dnia 12 marca 2004 roku o pomocy społecznej (Dz. U. z 2018 r. poz. 1508, z późn. zm.). 
stwierdza, że: „dziś coraz bardziej popularyzuje się idea miejskich asamblaży², które obejmują także inne formy sprawstwa [...] w relacjach horyzontalnych i ahierarchicznych. Gęstniejąca rzeczywistość miejska czyni problem społecznego aktywizmu niebywale złożonym, bowiem współczesna praxis nie jest już ukierunkowana na kształtowanie jednej, wspólnej przestrzeni publicznej, ale na produkowanie jej niezliczonych, nierzadko tymczasowych i zdelokalizowanych wariantów. Miejskie fora wyłaniają się i zanikają dynamicznie (Skórzyńska 2017, s. 59-60, 63-64).

\section{Doświadczenie punktowe}

W świetle dotychczasowych rozważań wokół doświadczenia spotkania w pracy socjalnej, a jednocześnie - za Aleksandrą Kunce: „otwierając się na opowieść o byciu we wspólnocie, nieustannie wychodzącej w stronę wykorzenienia i zakorzenienia [...], filozofia lokalności wychyla się w stronę tego, co wciąż ważne: locus i communitas [...]. Wyrasta ona $\mathrm{z}$ fragmentarycznych doświadczeń i obrazów, które współtworzą bycie w domu jako bycie w miejscu - w otwarciu, w odejściu, w powrotach, w przyjaźni, w spotkaniu. Ostatecznie bycie "W miejscu» powinno być złączone z byciem "na miejscu»" (Kunce 2016, s. 14).

Więcej, można podkreślić, że pracownik socjalny: „doświadczając przestrzeni najbliższej i tej najdalszej, podejmuje niepokojące powiązanie pojedynczego losu z ideą «bycia na miejscu» i tym, co «nie na miejscu». Życie w miejscu, jakkolwiek nadwerężone, pęknięte, jest naznaczone stygmatem przynależę do jakiegoś «tu», nawet gdy to, co okoliczne, odsłania «nigdzie», «gdzieś», «Wszędzie». Wysiłek podjęcia niepokoju miejsca jako zgody na niepoznawalne następuje w doświadczaniu miejsca” (Kunce 2016, s. 36-37).

Aleksandra Kunce podkreśla, że: „doświadczenie, otwarte na gęstość miejsca, zachowuje otwartość na to, co niepojęte i znane jednocześnie, co i odległe, i bliskie, co i indywidualne, i wspólnotowe, wreszcie, co i zmysłowe, i spekulacyjne. Wyobraźnia, odczucia, wiedza, wykładnia, doznania, zdarzenia, obrazy, los - wszystko to, co przynależy nam zarówno indywidualnie,

2 Za P. Celińską, asamblaż ( $\mathrm{z}$ fr. assemblage) to gromadzenie, technika wywodząca się z kolażu i oznaczająca dzieło powstałe z wykorzystaniem elementów trójwymiarowych. Pierwszy raz użyte przez Jeana Dubuffeta w 1950 roku, spopularyzowane w latach 60. XX wieku po wystawie The Art of Assemblage w 1961 roku w Nowym Jorku, https://zacheta.art.pl/pl/mediateka-i-publikacje/asamblaz (data pobrania: 5.01.2019). 
jak i zbiorowo, współtworzy nasze doświadczenie miejsca i nasze doświadczenie siebie w miejscu" (Kunce 2016, s. 37).

Autorka wskazuje, że: „otwarcie na tę wielość jest istotne w interpretowaniu doświadczenia miejsca. Jednak ta wielość prowadzi na grunt drobnych, pulsujących doświadczeń, które «dotykają» miejsca, a nie scalonego doświadczenia. Doświadczenie fragmentaryczne i mikroskopijne zarazem jest związane z naszym byciem w miejscu. Szlak mikrologiczny, znaczony drobnymi miejscami, śladami doświadczeń, jest wskazaniem nieskończonej sieci współtworzącej miejsca, w których istniejemy. Owy trakt punctum odsłania ważny wymiar doświadczenia umiejscowienia. Punkt jest nie tylko przestrzenno-czasowym śladem czy elementem zapisu, drobiną, ale jest jednocześnie tym, co porusza do głębi, sprawia ból, niepokoi. Punkty doświadczeń miejsca są tym, co porusza do głębi” (Kunce 2016, s. 39).

Jednocześnie A. Kunce stwierdza, że „doświadczenie punktowe jest zawsze niepełne, nieskończenie rozciągnięte $\mathrm{w}$ potencjalne odniesienia i możliwe do zaistnienia kształty. Zawsze się wymyka oswajającej wiedzy, a jednak po stronie punktowych doświadczeń widnieje przesmyk do tego, co rzeczywiste" (Kunce 2016, s. 41).

Tego doświadczenia poszukuje także praca socjalna. Praca socjalna jako działalność zawodowa ma na celu pomoc osobom i rodzinom we wzmacnianiu lub odzyskiwaniu zdolności do funkcjonowania w społeczeństwie poprzez pełnienie odpowiednich ról społecznych oraz tworzenie warunków sprzyjających temu celowi. Praca socjalna, wrażliwa na potencjalności społeczno-kulturowe miasta, dostrzega różnorodne miejsca aktywności lokalnej, centra twórczości, domy sąsiedzkie, spółdzielnie socjalne, instytucje kultury (zob. Kłosowski 2011; Kuligowski i in. 2014) oraz pomaga osobom korzystającym $\mathrm{z}$ tych miejsc ustanawiać kolejne relacje ludzkich doświadczeń w przestrzeni miasta. „Miejsca aktywności lokalnej to rożnego typu miejsca, które oprócz swojej codziennej działalności (bycia np. biblioteką), wspierają lokalne pomysły i działania społeczne mieszkańców. Robią to m.in. poprzez udostępnianie swojej przestrzeni na oddolne działania, podejmowanie współpracy z mieszkańcami i wspólne aktywizowanie sąsiadów" (UM Warszawa 2018). Taką właśnie pracę socjalną warto i trzeba rozwijać w świetle przedstawionych uwarunkowań miejskich.

Kontynuując rozważania za A. Kunce można wskazać, że: „antropologia każe opisywać i punkt abstrakcyjny, który jest obecny na rozrysowanej mapie, modelowo zawieszonej nad terenem, i punkt, który przez terytorium rzeczywiście zostaje wyodrębniony, jest namacalnym, empirycznie doświadczany. Punkt odczytujemy jako powściągliwie skupiony w miejscu, jest częścią otoczenia. Nie jest tylko statycznym punktem geometrii ludzkich skupisk, gdyż 
należy do działania. Układa się w linie, figury, które tworzą tkankę życia. Możemy poczytywać punkt za dynamiczny punt działań jako styk działania sił. Punkt to skumulowana aktywność. W punktach daje się uchwycić człowiek. Praca socjalna (przyp. - J.R.) obejmuje także refleksją człowieka w punktach jego skumulowanej aktywności. Komasuje to, co empiryczne i ogólne, co jest refleksją nad człowiekiem jako takim. Dlatego praca socjalna (przyp. - J.R.) potrzebuje punktu jako konstrukcji myślenia, aby uchwycić człowieka w jego doświadczeniu oraz odsłonić wiele szczegółowych i ogólnych wymiarów wiedzy o człowieku w czasoprzestrzeni” (Kunce 2008, s. 274-275).

Istotne, aby dla proponowanej refleksji o punktowo zorientowanej teorii i praktyce pracy socjalnej w mieście, dostrzec za A. Kunce, iż „punkt, który odsłania perspektywę widzenia, ale też doświadczanie i rozumienie rzeczy, ulega metamorfozie. Pokazuje, że to w punkcie uchwytny jest człowiek" (Kunce 2008 , s. 277-278).

\section{Plastyczność formy}

Wydaje się, że w perspektywie postawionej tezy swoją produktywność może okazać stosunkowo nowa we współczesnej humanistyce i - jak się wydaje - emanująca ożywczą mocą w naukach społecznych, ontologia przypadłości (w niej szczególnie teoria plastyczności) Catherine Malabou. Jak określa Malabou: „nie można uniknąć stwierdzenia, że każdy z nas pewnego dnia może stać się kimś innym, absolutnie innym. Najczęściej życie podąża swym torem jak rzeka. Właściwe mu zmiany i metamorfozy, dokonujące się w następstwie losowych zdarzeń i napotykanych trudności albo związane po prostu z naturalnym biegiem rzeczy, jawią się jako piętna i bruzdy ciągłego procesu spełniania. $Z$ czasem stajemy się wreszcie tym, czym jesteśmy. Mimo tego stopniowego egzystencjalnego i biologicznego schyłku, który tylko przekształca podmiot w niego samego, nie można zapomnieć, że tę samą tożsamość, pod pozorem elegancji cechuje - jak ujmuje to Catherine Malabou - wybuchowa moc plastiku. W następstwie ciężkich, traumatycznych przeżyć, czasem z byle przyczyny, tor się rozwidla i nowa osobowość, bez precedensu, współzamieszkuje $\mathrm{z}$ dotychczasową zajmując $\mathrm{w}$ końcu całą przestrzeń dla siebie. Jest to osobowość nie do poznania. Forma $\mathrm{z}$ wypadku zrodzona, przez przypadek powstała, rodzaj przypadłości” (Malabou 2017, s. 7-9).

Catherine Malabou odsłania owe przypadłości jako: „dziwne figury, powstające ze zranienia, albo i z niczego, $\mathrm{z}$ oderwania od wcześniejszego stanu, figury, które nie wynikają ani z nieuregulowanego konfliktu infantylnego, ani $\mathrm{z}$ nacisku treści wypartych, ani $\mathrm{z}$ niespodzianego powrotu jakiegoś fantomu. 
Istnieją przekształcenia które są zamachami. Swoiste fenomeny destrukcyjnej plastyczności - rozbite, nagle przerwane, opróżnione tożsamości osób chorych na Alzheimera, afektywne obojętności u niektórych osób z uszkodzeniami mózgu, u ludzi dotkniętych traumą, u ofiar naturalnych czy politycznych katastrof" (Malabou 2017, s. 9).

To właśnie: „pojęcie plastyczności umożliwia - w sposób istotny z punktu widzenia potrzeb "punktowej» pracy socjalnej - mówienie o metamorfozach podmiotu, a nie tylko o konstytuującej go różnicy, która zawsze jest już dana. Innymi słowy, plastyczny podmiot podlega procesowi nieustannej transsubiektywizacji, jego forma jest jego materią. Transsubiektywizacja, rozumiana jako wewnętrzna podróż podmiotu, jest zatem produktem transformacji. Mowa tutaj o transformacji, która na bazie opozycji między formami siebie zdolna jest wytworzyć nowy rodzaj podmiotowości” (Malabou 2016).

Ważne dla rozważnej filozofii plastyczności C. Malabou jest stwierdzenie Piotra Skalskiego, iż: „plastyczna istota zawiera w sobie potencjał de- i rekompozycji, metamorfozy, implikuje otwartość łańcucha przekształceń. Przeciwko sztywności formy plastyczność ustanawia podatność każdej formy na zmianę, przeciwko elastyczności plastyczność wymaga nieodwracalności efektu odkształcania i bezpowrotnej utraty źródła, przeciw giętkości plastyczność wprowadza opór i aktywność formy - twórczą zmianę przez zderzenie starego z nowym, gdzie przyjmowanie i utrzymywanie nowej formy jest równie istotne jak jej nadawanie. Istota plastyczna nie jest po prostu destrukcją wszelkiej tożsamości, lecz tworzy nowy rodzaj tożsamości - tożsamość metamorficzną. Podmiot nie jest już tylko formowany, lecz sam nadaje formę temu, co mu się przydarza - nadaje kształt swej przypadłości, formuje sam swoje przypadki” (Skalski 2017, s. 149, 154-156).

Piotr Skalski podkreśla, że: „plastyczność nie jest jednak wyłącznie mocą kreacji, jest również mocą destrukcji. Ontologiczny plastik to przypadłość, której asymilacja dokonuje się tylko przez własną eksplozję istoty, w taki sposób, że dopiero z pozostałych po niej skrawków formuje się zupełnie nowa tożsamość, «tożsamość ocalałego», indywiduum radykalnie odmienne w stosunku do siebie samego" (Skalski 2017, s. 156-157).

Jak wyjaśnia Hubert Kaszyński: „praca socjalna może mieć znaczący udział w ochronie ocalałego indywiduum, godności człowieka, jeśli będziemy ją ujmować jako profesję odpowiedzialną za zachowanie dynamicznej równowagi pomiędzy działaniami jednostek, grup środowisk społecznych, których celem jest podtrzymywanie konsensusu, jak również tych będących potencjalnym katalizatorem zróżnicowanych przejawów rozwoju i dekonstrukcji”" (Kaszyński 2013, s. 190). 
To niezwykle ważne dla myślenia o pracy socjalnej w perspektywie punktowych doświadczeń. Jednocześnie warto zauważyć za H. Kaszyńskim, że: „stabilna relacja z człowiekiem zagubionym w sobie i zagubionym w świecie umożliwia rozwój jego poczucia wartości oraz takich zdolności adaptacyjnych, dzięki którym może on wpływać na rzeczywistość. Odzyskiwanie przez człowieka poczucia sprawstwa pozwala na stopniowe włączanie w proces terapeutyczny rodziny oraz osób z jego najbliższego otoczenia, aby razem podjąć próbę porządkowania splotu makrostrukturalnych okoliczności blokujących szanse rozwojowe oraz definiowania zasobów, które mogą umożliwić zmianę. Troska o rozwijający się dialog, nauka słuchania, skupienie uwagi na tym, o czym mówi nasz podopieczny, o czym mówią jego najbliżsi są wyznacznikami współczesnej pracy socjalnej” (Kaszyński 2013, s. 190-191).

Jednocześnie H. Kaszyński podkreśla, że istotne są także „działania polityczne podejmowane $\mathrm{w}$ środowisku lokalnym. Ich szczególna rola polega na włączaniu w przestrzeń społeczną zdominowaną przez władzę i wiedzę ekspercką mikronarracji opartej na wiedzy pochodzącej z doświadczenia, które posiadają osoby dotknięte zranieniem chorobą, życiem, często doświadczające braku tolerancji”" (Kaszyński 2013, s. 190-191).

Podsumowując dotychczasowe rozważania wokół plastyczności, można zaznaczyć, iż praca socjalna wrażliwa na spotkanie człowieka, wyrastająca z pulsujących doświadczeń ludzkich losów, podejmuje wysiłek skutecznych działań pomocowych w ścisłym dialogu oraz troską o godność i sprawczość człowieka. Jednocześnie tak realizowana praca socjalna służy kreowaniu myślenia o wsparciu człowieka dotkniętego „osobliwą przypadłością" i odzyskania jego „punktowego” doświadczenia, podmiotowości dla wspólnoty lokalnej.

\section{Praca socjalna w mieście}

Wobec myślenia o pracy socjalnej zorientowanej na spotkanie z człowiekiem oraz sprzyjającej tworzeniu wspólnoty istotny jest splot podmiotowości człowieka i społecznej inkluzji. Maria Mendel wyjaśnia, iż: „troska o ludzki sens miasta może być rozumiana jako bezpośrednie odesłanie do problematyki, w której splatają się zagadnienia podmiotowości (w kontekście orientacji podmiotowej według Ewy Marynowicz-Hetki, 2006, s. 28, 33) oraz społecznej inkluzji, rozumianej jako realizacja postulatu solidarności w warunkach aktualnie rosnącej polaryzacji przestrzennej, zaznaczającej się gównie w przestrzeni miejskiej. Zagadnienia te stoją $\mathrm{w}$ centrum zainteresowania pracy socjalnej, ale w ten sposób splecione czynią ją szczególną, przede wszystkim w świetle pod- 
stawy, jaką owemu spleceniu daje myśl o znaczeniach wzajemnych układów, jakie powstają zarówno pomiędzy osobami i grupami potrzebującymi wsparcia a miejscami ich życia, jak i pracownikami socjalnymi, a miejscami, w których żyją beneficjenci udzielanego przez nich wsparcia" (Mendel 2014, s. 9).

W miejskim pejzażu owego splotu wzajemnych relacji, szczególna rola i odpowiedzialność przypada podejmowanej pracy socjalnej w mieście. To praca socjalna traktowana jako remedium na wyobcowanie, odrzucenie, traktowana jako odzyskiwanie człowieka powracającego do społeczeństwa, niekiedy trwale wpisanego w zniewalającą go przestrzeń. Jak pisze M. Mendel: „to praca socjalna, stanowiąca szczególną, bo nakierowaną na pomoc i wsparcie, interwencję we wspomnianą relację, która analizowana jest jako ciągłe umiejscawianie się człowieka, jako nieustanne ustosunkowywanie się do miejsca, a także stawanie wobec niego, jako wyzwania, kiedy pogrąża go ono lub wzmacniania, porywając do nowych przedsięwzięć. Stosownie do każdej z tych opcji, interweniująca praca socjalna jest specyficzną pracą, ale przede wszystkim współpracą na zmianę w kondycji życia podmiotu, której nieredukowalny opis sprowadza się do jego zdolności zmieniania, przekształcania miejsca, w którym żyje" (Mendel 2014, s. 10).

W świetle dotychczasowych analiz istotna jest perspektywa teoretyczna M. Mendel, wyjaśniająca iż: „praca socjalna jako interwencja w relację podmiot - miejsce znajduje swoją metateorię $\mathrm{w}$ pedagogice społecznej rozwijanej jako pedagogika miejsca. W związku z tym pedagogika miejsca, w kontekście pracy socjalnej i podbudowującego ją postulatu krzewienia wspólnotowych form życia lokalnych społeczności, może być rozumiana jako proces nieustającego rozrywania i twórczej, ukierunkowanej na wartości wspólnotowe renegocjacji znaczeń miejsc, w których jednostki i grupy są aktywne, współtworząc własne historie, siebie" (Mendel 2006, s. 32).

Namysł nad pracą socjalną $\mathrm{w}$ mieście $\mathrm{w}$ perspektywie spotkania $\mathrm{z}$ „punktowym”, niekiedy naznaczonym osobliwą przypadłością doświadczeniem człowieka, otwiera możliwości kreacyjne i emancypacyjne dla podejmowanej praktyki społecznej. Za M. Mendel: „można powiedzieć, że dzięki «byciu w świecie», dzięki miejscu, w którym człowiek żyje, ma on jedynie umożliwione wejście do gry znaczących. To, kim jest i kim będzie się stawał, nie jest i nie może być przez miejsce przesądzone. Wzajemność w dialektyce człowiek-miejsce możliwa do osiągnięcia poprzez działania, jest cechą rozwijającej się relacji. Mamy do czynienia z niekończącym się procesem. O człowieku, pozostającym w stałym dialogu z miejscem, można powiedzieć, że nie „jest”, lecz nieustannie „staje się” sobą. Pedagogika miejsca, zorientowana na pracę socjalną powinna zachowywać tego rodzaju świadomość i nie formo- 
wać człowieka (urabiać według wzoru), lecz pozwalać mu sobą się stawać" (Mendel 2006, s. 32).

Kazimiera Wódz przypomina, iż „Helena Radlińska pisała wiele lat temu, że praca społeczna «przetwarza środowisko siłami człowieka" i polega na „wydobywaniu i pomnażaniu sił ludzkich, na ich usprawnianiu i organizacji wspólnego działania dla dobra ludzi" (Wódz 1996, s. 32). W tym kontekście „praca społeczna oznacza działalność systematyczną, umożliwiającą w sposób umiejętny działanie nie tylko „dla społeczności”, ale i „poprzez społeczność”. Najważniejszym jej elementem jest dynamika podmiotu działającego, jego silna pozycja w społeczności (Marynowicz-Hetka 2012, s. 116-117). Praca socjalna, widziana z perspektywy społecznego wymiaru działania, ,jest aktywnością ukierunkowaną na zmianę i przekształcanie, a więc pewnym dynamicznym procesem zmian i przekształceń, ułatwiającym jednostkom i grupom włączanie się $\mathrm{w}$ relacje $\mathrm{z}$ samym sobą, $\mathrm{z}$ innymi i poprzez innych" (Marynowicz-Hetka 2012, s. 121-122). Takie postrzeganie pracy socjalnej zorientowanej na tworzenie warunków do rozwoju sił tkwiących w jednostce jak i środowisku, nabiera wymiaru animacyjnego, oznaczającego pobudzanie, stymulowanie zaangażowania jednostkowego i wspólnotowego w kierunku poprawy jakości życia.

Praca socjalna świadczona w celu poprawy funkcjonowania osób i rodzin w ich środowisku społecznym jest realizowana wobec różnych odbiorców, w tym osób z niepełnosprawnością i osób doświadczonych kryzysem psychicznym. Te przypadłości kreślą nowe kierunki działań pracy socjalnej na rzecz osób doświadczonych cierpieniem, będących mieszkańcami danej społeczności, którzy, jak pisze M. Mendel: „wydają się nie być jedynie obiektami w toczonym nad ich głowami dyskursie, lecz podmiotami o słabym głosie, zdolnymi jednak do uczynienia miasta przestrzenią własnego wpływu. Dosłownie i w przenośni opowiadają miasto, stając się jego twórcami, oraz wydreptują własną podmiotowość, przekształcając w ten sposób miejską przestrzeń i własne życie. Pracownik socjalny, mieszcząc się w proponowanej perspektywie, może dokonywać swoich interwencji w relację podmiot-miejsce, opowiadając i wędrując wraz z tymi, którym udziela wsparcia" (Mendel 2014, s. 14).

Praca socjalna splatająca zagadnienia podmiotowości i społecznej inkluzji otwiera się na opowieści ludzi dotkniętych różnorodnymi przypadłościami i zakorzenia je w przestrzeni miasta. Wyrazem takiego otwarcia był projekt „Ekspert przez Doświadczenie”, realizowany przez Miejski Ośrodek Pomocy Społecznej w Gdyni dla osób z doświadczeniem kryzysu psychicznego. „Projekt był realizowany dla 30 mieszkańców Gdyni od 01.06.2016 r. do 28.02.2018 r., współfinansowany z Europejskiego Funduszu Społecznego w ramach Regionalnego Programu Operacyjnego dla Województwa Pomorskiego na lata 
2014-2020” (MOPS Gdynia 2018). Realizatorzy przedmiotowego przedsięwzięcia wskazują, iż: „w trakcie realizacji projektu zaproponowano uczestniczkom i uczestnikom długotrwałe wsparcie w procesie rehabilitacji społecznej i zawodowej, tj. wsparcie pracownika socjalnego, doradcy osoby niepełnosprawnej, psychologa, doradcy zawodowego, trenera pracy oraz kursy zawodowe. Jednak największą wartość stanowiła możliwość uczestnictwa w kursie «Ekspert przez doświadczenie». Ta forma wsparcia prowadziła do zmiany sposobu myślenia na temat doświadczania kryzysu psychicznego - traktując go jako zasób i narzędzie do pracy z innymi osobami doświadczającymi podobnych trudności" (MOPS Gdynia 2018).

Pracownicy Miejskiego Ośrodka Pomocy Społecznej w Gdyni, zaangażowani we wsparcie osób z doświadczeniem kryzysu psychicznego podkreślają, iż: „kurs «Ekspert przez doświadczenie» miał przygotować jego uczestników do pełnienia roli eksperta pracującego $\mathrm{z}$ osobami chorującymi psychicznie. Kurs realizowano na podstawie europejskiego programu «EX-IN» (Experienced - Involvement). Dzięki doświadczeniom zdobytym podczas realizacji projektu, oferta Miejskiego Ośrodka Pomocy Społecznej w Gdyni wsparcia dla osób po kryzysach psychicznych została rozszerzona o nowy sposób aktywizacji społeczno-zawodowej" (Chotowska i in. 2017, s. 173-174).

Uczestnicy po zakończeniu kursu sami podejmowali nowe aktywności w przestrzeni miejskiej, w tym w szkołach, na konferencjach opowiadając o własnym doświadczeniu kryzysu psychicznego i powrocie do aktywności społecznej w mieście.

Wyzwaniem dla pracy socjalnej jest poszukiwanie przez pracownika socjalnego miejsc spotkania, praktykowania dialogu, gdzie współpracujący z nim ludzie dorośli, małoletni będą mieć możliwość konstruowania własnej wiedzy i wiedzy miasta, w którym żyją.

Miasto otwarte na doświadczenia ludzi dotkniętych przypadłościami, w tym także na skutek zdarzeń losowych, umożliwia im prezentację własnej twórczości w przestrzeni publicznej. Wyrazem tego była otwartość miasta na doświadczenie osobliwej przypadłości gdyńskiego malarza amatora Mirosława Śledzia, który w wyniku wypadku w dzieciństwie, malował kredkami i wykonywał prace plastyczne, aby łagodzić ból chorego narządu słuchu. Z czasem został określany jako geometrysta, prymitywista, twórca nowego stylu - kwadryzmu, zaliczanego do nurtu art-brut (zob. Jackowski 1995, 2005; Chlewiński 2009). Twórczość mieszkańca Gdyni została wielokrotnie prezentowana publicznie, również na wystawach prezentujących twórczość Mirosława Śledzia: „Śledź na śledzika” w 2016 roku w Gdyńskim Centrum Filmowym (CK Gdynia 2016), „Kim, do cholery, jest Mirek Śledź?” w Państwowej Galerii Sztuki 
w Sopocie w 2018 roku, której celem było „ukazanie pęknięcia między tym, co widoczne, a tym, co pozbawione widoku w świecie sztuki" (PGS 2018).

W kontekście pracy socjalnej, splatającej zagadnienia podmiotowości i społecznej inkluzji, warto wskazać koncepcję sztuki społecznej opracowanej przez Katarzynę Niziołek (Niziołek 2015). Badaczkę interesuje sztuka jako forma aktywności obywatelskiej. W tym celu wskazuje, że „pytanie o miejsce sztuki w społeczeństwie [...] staje się pytaniem o zakres twórczego uczestnictwa i dystrybucji uprawnień twórczych. Jest to pytanie o możliwości realizacji postulatu «sztuki ludzi» - jako jednej z form oddolnej aktywności społecznej, obywatelskiej, a nie «sztuki dla ludzi»" (Niziołek 2015, s. 20). Katarzyna Niziołek wyjaśnia, iż sztuka społeczna obejmuje „zbiór działań społecznych (indywidualnych lub zbiorowych) rozumianych wąsko, czyli intencjonalnych, świadomych, celowych, zorientowanych z jednej strony na kreację artystyczną (choć różnie rozkładających akcenty między procesem twórczym a jego efektem), z drugiej na proobywatelską i prodemokratyczną zmianę społeczną" (Niziołek 2015, s. 54).

W ramach podejmowanej pracy socjalnej warto poszukiwać odniesień do koncepcji sztuki społecznej (por. Wołodźko 2017; Sienkiewicz 2017) tworzonej przez „zwykłych ludzi”. Katarzyna Niziołek sztukę społeczną definiuje „przede wszystkim [...] poprzez pozaartystyczny, społeczny czy publiczny cel, któremu służy, oraz poprzez oddolny, prywatny charakter działania i zaangażowanych w nie podmiotów" (Niziołek 2015, s. 20). Zaproponowane przez badaczkę pojęcie sztuki społecznej nawiązuje do „utopijnej myśli niemieckiego artysty performera i działacza społeczno-politycznego Josepha Beuysa (1921-1986), który jako pierwszy używał terminów soziale Kunst (sztuka społeczna) i soziale Skulptur (rzeźba społeczna), rozszerzając pojęcie sztuki z twórczości artystycznej na całokształt ludzkiej aktywności w świecie" (Niziołek 2015, s. 26).

Jak wskazuje Chantal Mouffe: „praktyki artystyczne mogą odegrać decydującą rolę w konstruowaniu nowych form podmiotowości tylko dlatego, że korzystając z zasobów wywołujących reakcje emocjonalne, potrafią dotrzeć do człowieka na poziomie afektywnym. Na tym polega wielka siła sztuki - na jej zdolności do skłaniania nas, abyśmy spojrzeli na rzeczywistość w inny sposób, dostrzegli nowe możliwości. Dzieła sztuki przez to, jak pobudzają wyobraźnię i emocje, pozwalają nam uczestniczyć w nowych doświadczeniach i ustanawiać takie formy relacji, różniące się od tych, do jakich jesteśmy przyzwyczajeni" (Mouffe 2015, s. 103).

Refleksja nad pracą socjalną $\mathrm{w}$ mieście, $\mathrm{w}$ perspektywie spotkania $\mathrm{z}$ „punktowym”, niekiedy osobliwym doświadczeniem człowieka, otwiera możliwości kreacyjne i emancypacyjne dla podejmowanej praktyki społecznej. Tak 
odczytywana praca socjalna nadaje w przestrzeni publicznej nowych znaczeń aktualnej kondycji ludzkiej osób doświadczonych cierpieniem. Warto podkreślić za I. Sagan, że: „istnienie przestrzeni stanowiących fora swobodnego dostępu i wyrażania opinii jest niezbędne do realizacji politycznego wymiaru życia miejskiego, którego rozumienia nie należy ograniczać do udziału w ruchach społecznych bądź w zinstytucjonalizowanych procesach politycznych. Działalność polityczna to także indywidualne i zbiorowe, oficjalne i prywatne, racjonalne i emocjonalne działania, oddziaływania i wpływy, które kształtują charakter koegzystencji i wspólnotowość stosunków społecznych" (Sagan 2017, s. 133). Jednocześnie, jak zauważa: „przestrzeń publiczna demokratycznie otwarta dla wszystkich użytkowników tworzy warunki spotkania «obcego», umożliwiające koegzystencję różnych grup społecznych. Pozwala uczyć się akceptowania i włączania «innego» w rodzime kontakty i styl życia. Obecność przestrzeni publicznych pełni rolę stymulatora $\mathrm{w}$ formowaniu otwartej, inkluzywnej społeczności. Ponieważ przestrzenie publiczne tworzą warunki umożliwiające gromadzenie się, przebywanie razem, rozpoznawanie zbieżności poglądów, wspólnoty interesów różnych grup społecznych - ich obecność ma znaczenie esencjonalne w funkcjonowaniu systemu demokratycznego" (Sagan 2017, s. 135-136).

$\mathrm{W}$ tak rozumianej przestrzeni miasta nieustannie tworzą się nowe podmioty, wrastające w życie miasta. Należy podkreślić za Magdaleną Matysek-Imielińską, iż „stają się tym samym słyszalnymi, widzialnymi, cielesnymi, obecnymi aktorami. Emancypacja i równość stanowią wstępny warunek zmiany rzeczywistości. Takie społeczne rozumienie emancypacji opiera się na współpracy i wspólnym wytwarzaniu praktyk, na uspołecznieniu zdolności i umiejętności każdego podmiotu uczestniczącego w tym procesie" (Matysek-Imielińska 2018, s. 380-381).

Można za M. Mendel stwierdzić, że: „życie w mieście, przebiegając we względnej bliskości fizycznej i szczególnym, miejskim stylu - owocuje zawsze pewnym wzajemnym wpływem, zaś towarzyszące mu stymulacje generują określoną wiedzę, postawy i orientacje wobec rzeczywistości, wzory myślenia i związane z nimi dyspozycje do zachowań oraz obyczajowość, rytualizacje. Ich współwystępowanie skutkuje odrębnością kulturową - kulturą miasta" (Mendel 2017, s. 54).

Jednocześnie można także, jak zrobiła to M. Mendel: „wyodrębnić element kultury miasta, odnoszący się do jej edukacyjnych wymiarów, i nazwać go kulturą edukacyjną miasta. Kultura edukacyjna może być - z jednej strony - wiedzą współtworzących miasto jego użytkowników, ukształtowaną w toku stymulacji, nieustannie zachodzących w skondensowanej społecznie przestrze- 
ni. Kultura ta może tkwić $\mathrm{w}$ ich postawach i orientacjach wobec rzeczywistości, wzorach myślenia i dyspozycjach do zachowań. Z drugiej natomiast strony kultura edukacyjna miasta może ustanawiać istotny kontekst i konkretne warunki, w których powstaje owa wiedza, postawy, orientacje, dyspozycje. W obu przypadkach jest zarówno procesem, jak i strukturą, przez które można ją produktywnie badać i rozwijać" (Mendel 2017, s. 54-55).

\section{Koinopolis}

Wobec dotychczasowych rozważań warto podkreślić za M. Mendel, że: „miasto to również wiedza, warunkująca publico bono i żywotność kształtującej je społeczności, oraz warunki do operacjonalizacji tej wiedzy w określonej przestrzeni - miejscach miasta. To wiedza koinopolityczna, wiedza produkowana i użytkowana przez miasto, które dzięki niej i wokół niej buduje swoją odporność i prężność i zarazem specyfikę, tożsamość. W kształtowaniu tej wiedzy doniosłą rolę odgrywają twórcy miasta - „zwykli mieszkańcy” oraz wszelkie ciała miastem zarządzające" (Mendel 2017, s. 59).

Pozostając w tak odczytywanej perspektywie miasta, praca socjalna znajduje wiele inspiracji i możliwości skutecznych działań, transformujących środowisko społeczne. Korzystając z miejskich zasobów kulturowych, społecznych podejmowana praca socjalna ma szerokie możliwości wniesienia wkładu w dotychczasowe zasoby wiedzy społeczności lokalnej. Ich punktowe wydobycie $\mathrm{z}$ udziałem osób objętych wsparciem pracownika socjalnego w ramach różnorodnych form aktywności, zaangażowania w wydarzenia społeczne, w tym organizacja i udział w prezentacjach twórczości, otwartych spotkaniach z mieszkańcami i zaproszonymi gośćmi w galeriach sztuki, galeriach handlowych, bibliotekach publicznych, szkołach, domach sąsiedzkich, z jednej strony zasila i multiplikuje społeczne zasoby wiedzy, a $\mathrm{z}$ innej zasila jednostkową biografię człowieka o doświadczenia kreacyjne i rozwojowe w mieście. M. Mendel zauważa, że „miasto w różnych obszarach swojego życia wykazuje zdolność do uczenia (się) i nauczania; jest miejscem edukacyjnym. To locus co-educandi, czyli miejsce edukacyjne, w którym charakterystycznie doświadczenie edukacyjne jest wzajemnie podzielane" (Mendel 2017, s. 66).

Traktowanie pracy socjalnej jako praktyki społeczno-kulturowej kreującej społeczny potencjał wiedzy ma swoje wyjaśnienie w pogłębionej refleksji teoretycznej M. Mendel. Badaczka wyjaśnia, iż „pedagogika miasta, analogicznie wobec pedagogiki miejsca, rozumiana jest jako obszar skoncentrowany na mieście, lokującej się w myśli przestrzennej refleksji teoretycznej, oraz obszar praktyki społeczno-edukacyjnej i kulturowej" (Mendel 2017, s. 64-65). 
Maria Mendel rozwijając rozważania o mieście jako miejscu wspólnym, przedstawia swoją koncepcję ugruntowaną w Arystotelesowskim pojęciu koinopolis. Badaczka wyjaśnia, że: „dla Arystotelesa lokalny wymiar miejsca miał kluczowe znaczenie dla pojmowania polis. Kiedy Arystoteles wprowadza swój neologizm: koinópolis, zlepiające przymiotnik koinós (wspólny) i polis (miasto-wspólnotę), ma na uwadze specyficzną styczność komunikacyjną i intelektualną, właściwą miejscu fizycznemu, przestrzeni zagospodarowanej przepływami ludzkiego myślenia. Miasto jest tu miejscem wspólnym; topos lokalnym i wyrazem kulturowej «tutejszości». Na tej podstawie można odczytywać koinópolis jako rodzaj lokalnego, zachodzącego w mieście po-rozumienia, czyli rozumienia które jest podzielane w nim wspólnotowo i które tworzy miejską wspólnotę. To wspólnota komunikacyjno-intelektualna, na podstawie wypracowanych sieci znaczeniowych zdolna do dalszych autorefleksji. To miasto, będące aktywną i nieograniczenie twórczą, samo-wytwarzającą się "myślą stąd», wspólną i lokalną" (Mendel 2017, s. 70-72).

Maria Mendel przekonuje, że: „wspólnota myśli lokalnej uczy, generując wiedzę, kształtując postawy, dyspozycje do określonych zachowań. Miasto czyni to przez miejsce, jakim się staje, kiedy zadzierzgnięte $\mathrm{w}$ nim zostaną pierwsze toposy i podzielane rozumienie osiąga fazę autopoiezy (gr. auto samo i poiesis - wytwarzanie). Ludzie uczą się wówczas nie tylko «od siebie», lecz «od» $\mathrm{i}$ «Z» miasta, w tej sytuacji iście pedagogicznego; miasta, operującego wiedzą samowystarczalną i pożytkującą efekt synergii, powstający "pomiędzy» komunikacyjnymi przepływami (Mendel 2017, s. 72).

Katarzyna A. Klimowicz w odniesieniu do doświadczeń miejskich stolicy Katalonii stwierdza, że: „włączanie najczęściej wykluczonych oraz dyskryminowanych grup społecznych - dzieci, młodzieży, kobiet, imigrantów, społeczności queer, osób z różnego rodzaju niepełnosprawnością, seniorów, wpisuje się w rozwój demokracji partycypacyjnej i deliberatywnej. Otwieranie procesów podejmowania decyzji w mieście ma na celu wykorzystanie doświadczeń mieszkańców oraz ich różnorodnego potencjału i pokładów kreatywności zbiorowej. Takie podejście właśnie odpowiada na globalne wyzwania i zagrożenia (globalne zmiany klimatyczne, zanieczyszczenie środowiska, rosnące nierówności społeczno-ekonomiczne), wobec których konieczna jest lokalna i transnarodowa współpraca oraz solidarność" (Klimowicz 2017, s. 60).

Polityka świadomego kształtowania nowej rzeczywistości społecznej opartej na wzajemnym zaufaniu w lokalnych wspólnotach i partycypacyjnym zarządzaniu wspólnymi zasobami wyrasta właśnie z kategorii myślenia o koinopolis.

Znaczące dla refleksji o pracy socjalnej w mieście jest podjęcie punktowego doświadczenia człowieka, rozważanego we wcześniejszej części artyku- 
łu i wydobycie go na rzecz poszerzania doświadczenia lokalnego. A. Kunce stwierdza, że: „doświadczenie lokalne tonie w konkretach: gestach, słowach, czynach, spojrzeniach, ruchach, dotyku, w podtrzymywaniu i powtarzaniu tej misternej sieci wiążącej człowieka $\mathrm{z}$ miejscem. Niełatwo artykułowane, jest wsparte na obecności i podtrzymywaniu życiu uzbrojonego w lokalne traktaty ars bene vivendi i ars bene moriendi. $\mathrm{W}$ doświadczeniu lokalnym drzewo życia i drzewo poznania są splecione $\mathrm{w}$ jakimś namacalnym miejscu, $\mathrm{z}$ odpowiedzialnością «tu» $\mathrm{i}$ «teraz», $\mathrm{z}$ troską o to, co jest okoliczne. Splecione wspólnoty, miejsca i osoby stanowi triadę, na której wspiera się doświadczenie lokalne (Kunce 2016, s. 44).

Praca socjalna traktowana jako proces odzyskiwania człowieka powracającego do społeczeństwa, może kształtować wspólnotę współmieszkańców, a tym samym wspólnotę myśli lokalnej wytwarzającą wiedzę społecznie użyteczną na rzecz porozumienia i współpracy.

Wobec tak rozumianej refleksji o pracy socjalnej w przestrzeni praktyk społecznych na rzecz rozwijania wspólnotowego miasta ważne są rozważania B. Skrzypczaka dotyczące kategorii zmiany, które mogą być inspiracją dla podejmowanej aktualnie pracy socjalnej. Badacz wskazuje, iż: „we współczesnych naukach humanistycznych i społecznych od kilku lat mówi się o «zwrocie performatywnym», metodologii performatywnej, o szerokiej interdyscyplinarnej tendencji, w której ponownie docenia się rolę sprawczego podmiotu w przekształcaniu światów społecznych. Performance akcentuje bycie sprawcą przemian, a nie ich obiektem. Zwykła aktywność już nie wystarcza, nie prowadzi do zmiany. By zmiana była skuteczna, musimy skierować siłę na samą konstrukcję/ramę, naruszać ją, nie zadawalać się celami pozornymi/krótkodystansowymi. W centrum zainteresowań zostają postawione zatem kategorie zmiany jako wartości pozytywnej oraz aktywny (sprawczy) podmiot (podmiot performatywny), który tworzy się poprzez zmiany i powoduje konkretne zmiany w otaczającym świecie (Mendel, Skrzypczak 2014, s. 28).

\section{Zakończenie}

Przestrzeń miasta jest przestrzenią ludzkiego doświadczenia, które - jak przedstawiała to argumentacja tez tego tekstu - punktowo naznacza człowieka. W rezultacie realizacji pracy socjalnej wrażliwej na doświadczenia człowieka, w tym doświadczenia osobliwych przypadłości, kryzysów zdrowotnych, możliwe staje się kreowanie zmiany społecznej, budowanie mostów porozumienia pomiędzy aktywną częścią społeczności lokalnej a członkami tej społeczności, którzy jeszcze nabierają sił, aby włączyć się w życie społeczne. Tym 
samym kształtuje się wspólnota ucząca swoich członków tak, że każdy z nich uczy siebie nawzajem.

Wyzwaniem dla pracy socjalnej jest poszukiwanie przez pracownika socjalnego miejsc spotkania, praktykowania przez jego podopiecznych dialogu w mieście, gdzie wspólnie $\mathrm{z}$ jego mieszkańcami będą mieć możliwość konstruowania własnej wiedzy oraz wiedzy miasta, w którym żyją. Miejscami, $\mathrm{w}$ których umożliwia się prezentowanie wiedzy społecznie wytwarzanej mogą być instytucje publiczne, w tym realizujące pracę socjalną oraz miejsca aktywności lokalnej, które stają się miejscami edukacyjnymi na rzecz społeczności lokalnej.

Praca socjalna $\mathrm{w}$ mieście realizowana $\mathrm{w}$ dialogu $\mathrm{z}$ otoczeniem społecznym i kulturowym mieszkańców określonej społeczności jest praktyką społeczną, która wytwarza wiedzę lokalną służącą wszystkim współmieszkańcom. Dyskutowana społecznie kondycja miasta i wypracowywana wizja jego rozwoju, z uwzględnieniem różnorodnych doświadczeń mieszkańców, ma charakter formacyjny w budowaniu wspólnoty lokalnej i kultury edukacyjnej miasta.

Praktyki na rzecz włączania w życie miasta różnorodnych doświadczeń punktowych, $\mathrm{w}$ tym doświadczeń osobliwych przypadłości mieszkańców miasta może stanowić decydujący etap na drodze budowania koinopolis. Myślenie o atrakcyjności miasta jako locus co-educandi (Mendel 2017) pozwala wyrastać poza ekonomiczną logikę globalnego urbanizmu (Szmytkowska, Sagan 2012) i na jego użytek stosowanego marketingu miejsc. To myślenie o mieście otwartym na doświadczanie spotkań, mieście zapraszającym wszystkich mieszkańców do debat, współpracy, prezentacji własnej twórczości oraz wypracowywania wiedzy lokalnej i partycypacyjnych praktyk lokalnych, może nadać miejskiej wspólnocie siły i witalności twórczej.

Warto powtórzyć, że prawo do miasta to znacznie więcej niż indywidualna wolność dostępu do zasobów miejskich, to prawo do zmieniania siebie poprzez zmienianie miasta. W takim odczytaniu miasta i doświadczeń człowieka możliwe staje się podejmowanie pracy socjalnej na rzecz społecznej inkluzji i rozwoju podmiotowości mieszkańców miasta.

Tym samym praca socjalna poszukująca i pozostająca $\mathrm{w}$ relacji $\mathrm{z}$ doświadczeniem człowieka kreuje przestrzeń spotkania wyzwalającą od cierpienia i zagubienia społecznego. To praktyka społeczna wrażliwa na historie ludzkiej nieobecności w życiu miasta, w którym mieszkańcy prezentując własne narracje i współtworząc wspólne działania, zarazem budują siebie we wspólnym mieście - koinopolis. 


\section{Literatura}

Chlewiński Z. (red.), (2009), Od egzekucji do uniewinnienia, Muzeum Mazowieckie, Płock.

Chotowska K., Zadrożna A., Harchaj P., (2017), I Pomorskie Forum Samopomocy Osób z Doświadczeniem Kryzysu - Dobre praktyki i przyszłość, „Praca Socjalna”, 4, s. 171-177.

Jackowski A., (1995), Sztuka zwana naiwną. Zarys encyklopedyczny twórczości w Polsce, Wydawnictwo Krupski i S-ka, Warszawa.

Jackowski A., (2005), Świat Nikifora, Słowo/Obraz Terytoria, Gdańsk.

Kaszyński H., (2013), Praca socjalna z osobami chorującym psychicznie. Studium socjologiczne, Wydawnictwo Uniwersytetu Jagiellońskiego, Kraków.

Klimowicz K.A., (2017), Democracia real ya!, „Magazyn Miasta”, 1(16), s. 58-61.

Kłosowski W. (red.), (2011), Kierunek kultura. W stronę żywego uczestnictwa w kulturze, Mazowieckie Centrum Kultury i Sztuki, Warszawa.

Kuligowski W., Michałowski L., Stachura K., Zbieranek P., (2014), Poszerzanie pola kultury. Sektor publiczny wobec zmian, „Kultura Współczesna”, 3(83).

Kunce A., (2008), Antropologia punktów. Rozważania przy tekstach Ryszarda Kapuścińskiego, Wydawnictwo Uniwersytetu Śląskiego, Katowice.

Kunce A., (2016), Człowiek lokalny. Rozważania umiejscowione, Wydawnictwo Uniwersytetu Śląskiego, Katowice.

Malabou C., (2017), Ontologia przypadłości. Eseje o plastyczności destrukcyjnej, przeł. P. Skalski, Fundacja Augusta hrabiego Cieszkowskiego, Warszawa.

Malabou C., Vahanian N., (2016), To samo jest różne, „ZNAK”, kwiecień, nr 731.

Matysek-Imielińska M., (2018), Miasto $w$ działaniu. Warszawska Spółdzielnia Mieszkaniowa dobro wspólne w epoce nowoczesnej, Fundacja Bęc Zmiana, Warszawa.

Marynowicz-Hetka E., (2006), Pedagogika społeczna. Podręcznik akademicki, t. 1, Wydawnictwo Naukowe PWN, Warszawa.

Marynowicz-Hetka E., (2012), Społeczny wymiar działania w polu praktyki socjalnej: istota i sens, „Zoon Politikon: rocznik naukowy”, (3), s. 109-127.

Mendel M., (2014), O ludzki sens miasta. Wprowadzenie do pracy socjalnej jako interwencji $w$ relacje podmiot-miejsce, [w:] Wybrane problemy pracy socjalnej $w$ mieście, J. Sokołowska, M. Szpunar, J. Wojciechowska (red.), Wydawnictwo Uniwersytetu Gdańskiego, Gdańsk, s. 9-15.

Mendel M., (2017), Pedagogika miejsca wspólnego. Miasto i szkoła, Wydawnictwo Naukowe Katedra, Gdańsk.

Mendel M. (red.), (2006), Pedagogika miejsca i animacja na miejsce wrażliwe, [w:] Pedagogika miejsca, Wydawnictwo Naukowe Dolnośląskiej Szkoły Wyższej Edukacji TWP, Wroclaw, s. 21-37.

Mendel M. (red.), (2016), Miasto pedagogiczne, „Studia Pedagogiczne”, nr 69.

Mouffe Ch., (2015), Agonistyka. Polityczne myślenie o świecie, Wydawnictwo Krytyki Politycznej, Warszawa.

Sagan I., (2017), Miasto. Nowa kwestia i nowa polityka, Wydawnictwo Naukowe SCHOLAR, Warszawa.

Sienkiewicz K., (2017), Patriota wszechświata. O Pawle Althamerze, Wydawnictwo Karakter, Kraków, Muzeum Sztuki Nowoczesnej, Warszawa.

Skalski P., (2017), Plastyczność istnienia, [w:] C. Malabou, Ontologia przypadłości. Eseje o plastyczności destrukcyjnej, Fundacja Augusta hrabiego Cieszkowskiego, Warszawa, s. 146-165. 
Skórzyńska A., (2017), Praxis i miasto. Ćwiczenia z kulturowych badań angażujących, Instytut Badań Literackich PAN, Warszawa.

Skrzypczak B., (2014), Laboratorium Innowacji Społecznej: wspólnota dialogu, siła współdecydowania, [w:] Organizowanie społeczności lokalnej. Wspólnoty zmiany, M. Mendel, B. Skrzypczak (red.), Centrum Wspierania Aktywności Lokalnej CAL, Fundacja Instytut Spraw Publicznych, Warszawa, s. 19-43.

Sokołowska J., Szpunar M., Wojciechowska J. (red.), ze wstępem Marii Mendel, (2014), Wybrane problemy pracy socjalnej w mieście, Wydawnictwo Uniwersytetu Gdańskiego, Gdańsk.

Szmytkowska M., Sagan I. (red.), (2012), Miasto $w$ dobie neoliberalnego urbanizmu, Wydawnictwo Uniwersytetu Gdańskiego, Gdańsk.

Tischner J., (1994), Myślenie według wartości, Wydawnictwo Znak, Kraków.

Tischner J., (2006), Filozofia dramatu, Wydawnictwo Znak, Kraków.

Wołodźko A., (2017). Spotkania i mikroutopie. Sztuka partycypacyjna w Skandynawii. Gdańsk: Fundacja „Kultury ponad kulturą".

Wódz K., (1996), Praca socjalna w środowisku zamieszkania, Interart, Warszawa.

\section{Źródła internetowe}

CK Gdynia, (2016). Wystawa prezentująca twórczość Mirosława Śledzia, http://www.ckgdynia. pl/sledz-na-sledzika-wystawa-miroslawa-sledzia/ (data pobrania: 17.09.2018).

MOPS Gdynia, (2018). Ekspert przez Doświadczenie, http://epd.mopsgdynia.pl/o-projekcie (data pobrania: 12.09.2018).

Niziołek K., (2015), Sztuka społeczna. Koncepcje - dyskursy - praktyki, https://repozytorium. uwb.edu.pl/jspui/bitstream/11320/4408/1/Niziołek\%20Katarzyna_Sztuka\%20społeczna_ tom\%20I.pdf (data pobrania: 2.03.2019).

PGS, (2018), Wystawa prezentująca twórczość Mirosława Śledzia. https://www.pgs.pl/wpisy/kim-do-cholery-jest-mirek-sledz (data pobrania: 27.10.2018).

UM Warszawa, (2018), Miejsca Aktywności Lokalnej, https://inicjatywa.um.warszawa.pl/mal (data pobrania: 10.09.2018). 